\title{
Comparative Analysis Method of Certainty Factor, Dempster-Shafer, and The Probability of Damages Bayes Drone
}

$1^{\text {st }}$ Victor Amrizal $^{1}, 2^{\text {nd }}$ Rifal Nofri Yansyah ${ }^{1}, 3^{\text {rd }}$ Siti Ummi Masruroh $^{1}, 4^{\text {th }}$ Dewi Khairani $^{1}$ \{victor.amrizal@uinjkt.ac.id ${ }^{1}$, rifal.nofriyansyah14@mhs.uinjkt.ac.id ${ }^{1}$, ummi.masruroh@uinjkt.ac.id ${ }^{1}$ \}

UIN Syarif Hidayatullah, Jakarta Indonesia ${ }^{1}$

\begin{abstract}
Drone unmanned aircraft. This aircraft is controlled automatically by a computer program that is designed, or by remote control from the pilot contained in the plains or in other vehicles. Technological developments make drones also began to be applied to civilian purposes, mainly in the fields of business, industry and logistics. Even so, the drones are still reaping a lot of criticism from many quarters. In addition, the results of interviews with the author of the drones in a community electronic media is kaskus.co.id, drones users still complain availability of spare parts and also the place of service drone that still can not be reached in all regions in Indonesia, even in the city was the lack of availability of service centers is still perceived audience of drones be a trigger factor for the difficulty of drones could be accepted by society. One solution to address the destruction of the drones is to implement systems that provide information. Based on the problems above, one way to minimize the damage of drones is by making expert system. This expert system is one branch of artificial intelligence (Artificial Intelligence), who learn how to adopt an expert way of thinking in solving a problem, making a decision and draw conclusions from the facts. In this study, the authors compared the results of three methods, namely expert system Dempster Shafer method, the method of Certainty Factor, Bayesian probability method. To compare the results of the third output method based on parameters Accuracy, Recall, precission and Error Rate.
\end{abstract}

Keywords: Expert System, Certainty Factor, Dempster Shafer, Bayesian probability, Artificial Intelligence, Certainty Factor, Damage drones, CodeIgniter, CSS, JavaScript.

\section{Introduction}

Drone pilotless aircraft. This aircraft is controlled automatically by a computer program that is designed, or by remote control from the pilot contained in the plains or in other vehicles.

Technological developments make drones also began to be applied to civilian purposes, mainly in the fields of business, industry and logistics. Even the procurement of drones become one of the programs that will be implemented by the President Jokowi as a tool to maintain the defense, security, and sovereignty of the Republic of Indonesia [5].

Drone still reap a lot of criticism from various circles of society. One problem that is still being studied in the application related to location, altitude drones are flying. Drone is at the same level with the aircraft altitude which makes it potentially collide with aircraft when airborne [5]. 
And it can lead to damage to the drone, but it is most people are not technically trained so that if damage to the drone can not understand how to improve and overcome.

Society requires a more practical system that has the ability like an expert in diagnosing a malfunction. The system is an expert system. To create an expert system is usually used theories which have a respective method and can be applied to expert systems, which according to Giarratano and Riley that the expert system must be able to work in uncertainty [4].

Based on the problems that have been outlined above there are some things you would like the author to convey, among others:

1. Constructing a system or application that implements an expert system to help people know existing damage to the drone.

2. Provide an education and information to the public will damage existing knowledge about the drones.

3. Expert help in detecting damage to what is indicated on the drones they will handle.

4. Doing Comparison of results from multiple methods of expert systems with output parameters that have been determined.

On Several previous studies comparing Certainty Factor and Dempster Shafer used by Emanuel Riolan in research entitled "Analysis Comparison of Methods Dempster-Shafer Method Certainty Factor In Disease Diagnosis Son" who conducted an analysis of the calculation algorithm and the result is to be recalculated results of the two algorithms use Confusion Matrix theory Certainty Factor algorithm has a 96.03\% accuracy value better than Dempster-Shafer algorithm which has a value of 94.44\% accuracy [4]. Additionally Amanda in her study also did a comparison of Certainty Factor and Dempster-Shafer to the calculation result of "Diagnosis of Diabetes Mellitus" by doing a T test of both algorithms DempsterShafer method results are more significant than the method of Certainty Factor 0.05 [1].

A comparison with previous similar studies, concluded the research made by the author can be developed using three methods including Certainty Factor, Dempster Shafer, Bayesian probability, by calculating the results of the comparison between the 3 methods use parameters Accuracy, precission, Recall, and Error Rate.

\section{Previous Study}

Expert System Expert systems or commonly referred to as Besed Knowledge System is a computer application that is shown to aid decision-making or prevention of problems in specific areas. The system works by using the knowledge and methods of analysis have been defined in advance by experts according to their expertise. This system is called the expert system for the function and its role as an expert who should have the knowledge, experience in memecahakan issue problem [2].

Factor certainty(Certainty Factor) introduced by Buchanan in the manufacture MYCIN Shortliffe (Wesley, 1984). Certainty Factor (CF) is a clinical parameter values given MYCIN to show how much confidence. Certainty Factor is defined as follows. $\mathrm{CF}(\mathrm{H}, \mathrm{E})=\mathrm{MB}(\mathrm{H}, \mathrm{E})$ $\mathrm{MD}(\mathrm{H}, \mathrm{E})$.

$\mathrm{CF}(\mathrm{H}, \mathrm{E})$ : Certainty Factor of hypothesis $\mathrm{H}$ which is influenced by the facts (evidence) $\mathrm{E}$. The amount of CF ranging from -1 to 1 . A value of -1 indicates an absolute distrust while the value of 1 indicates absolute confidence. 
MB (H, E): the size of the increase in confidence (measure of Increased belief) of the hypothesis $\mathrm{H}$ that are affected by the symptoms of $\mathrm{E}$.

$\mathrm{MD}(\mathrm{H}, \mathrm{E})$ : the size of the increase in distrust (measure of Increased disbelief) against the hypothesis $\mathrm{H}$ that are affected by the symptoms of $\mathrm{E}$ [9].

To calculate the value of $\mathrm{CF}$ to use the formula:

$\mathrm{CF}(\mathrm{H}, \mathrm{E})=\mathrm{MB}(\mathrm{H}, \mathrm{E})-\mathrm{MD}(\mathrm{H}, \mathrm{E})$

Formula combination rule with different evidence and hypothesis $\mathrm{H} \mathrm{E}$ alike:

$$
\begin{aligned}
& C F_{\text {coiraine }} C F(H, E)_{1,2}=C F(H, E)_{1}+C F(H, E)_{2}=\left[1-C F(H, E)_{4}\right] \\
& C F_{\text {combine }} C F(H, E)_{\text {oid }: 3}=C F(H, E)_{\text {old }}+C F(H, E)_{3}=\left[1-C F(H, E)_{\text {oid }}\right]
\end{aligned}
$$

Dempster-Shafer is a theory that is capable of handling a variety of possibilities to combine the possibilities with the facts.

In the Dempster-Shafer theory there are various conflicts that are united to combine various information.

A collection of information that is different and menyeluruhdalam this theory is known as the frame of discernment which is denoted by q (theta) [3].

In calculating the Dempster Shafer method using the formula:

$$
\mathrm{m} 3(\mathrm{Z})=\frac{\sum x n y=z \mathrm{~m} 1(\mathrm{X}) \cdot \mathrm{m} 2(\mathrm{Y})}{1-\sum x n y=q m 1(X) \cdot \mathrm{m} 2(\mathrm{Y})}
$$

Bayes theorem is used to calculate the probability of occurrence of an event based on the effect obtained from the observation. Beside these memanfaakan Bayes methods of sample data obtained from population also takes into account an initial distribution called prior distribution.

Bayes method also looked at as a variable parameter that describes the initial knowledge about the parameters before the observations were made and expressed in a distribution called prior.Setelah distribution of the observations were made, the information in the prior distribution combined with sample data through Bayes theorem [17].

Thomas Bayes, describes the relationship between the conditional probability of two events is a good way to deal with uncertainty data using Bayes formula which is expressed by the following formula:

$$
\mathrm{P}\left(\mathrm{H}_{\mathrm{i}} / \mathrm{E}\right)=\frac{\mathrm{P}\left(\mathrm{E} / \mathrm{H}_{\mathrm{i}}\right)^{*}\left(\mathrm{P}\left(\mathrm{H}_{i}\right)\right.}{\sum_{\mathrm{k}=1}^{\mathrm{n}} \mathrm{P}\left(\mathrm{E} / \mathrm{H}_{\mathrm{k}}\right)^{*}\left(\mathrm{P}\left(\mathrm{H}_{\mathrm{k}}\right)\right.}
$$

\section{Methods}

There are different types of lifecycle (Madani: 1990) which can be used for studies on modeling and simulation. There are basic steps that should be considered in the simulation study. Lifecycle should not be interpreted as a strict sequential is iterative, and sometimes also the transition in the opposite direction.

The steps in the simulation method is as follows [14]:

a. problem Formulation

b. Conceptual Model

c. Collection of Input / Output Data

d. modeling Phase 
e. Simulation Phase

f. Conclusion (Verification, Validation, and Experimentation). Here is a plot of research conducted:

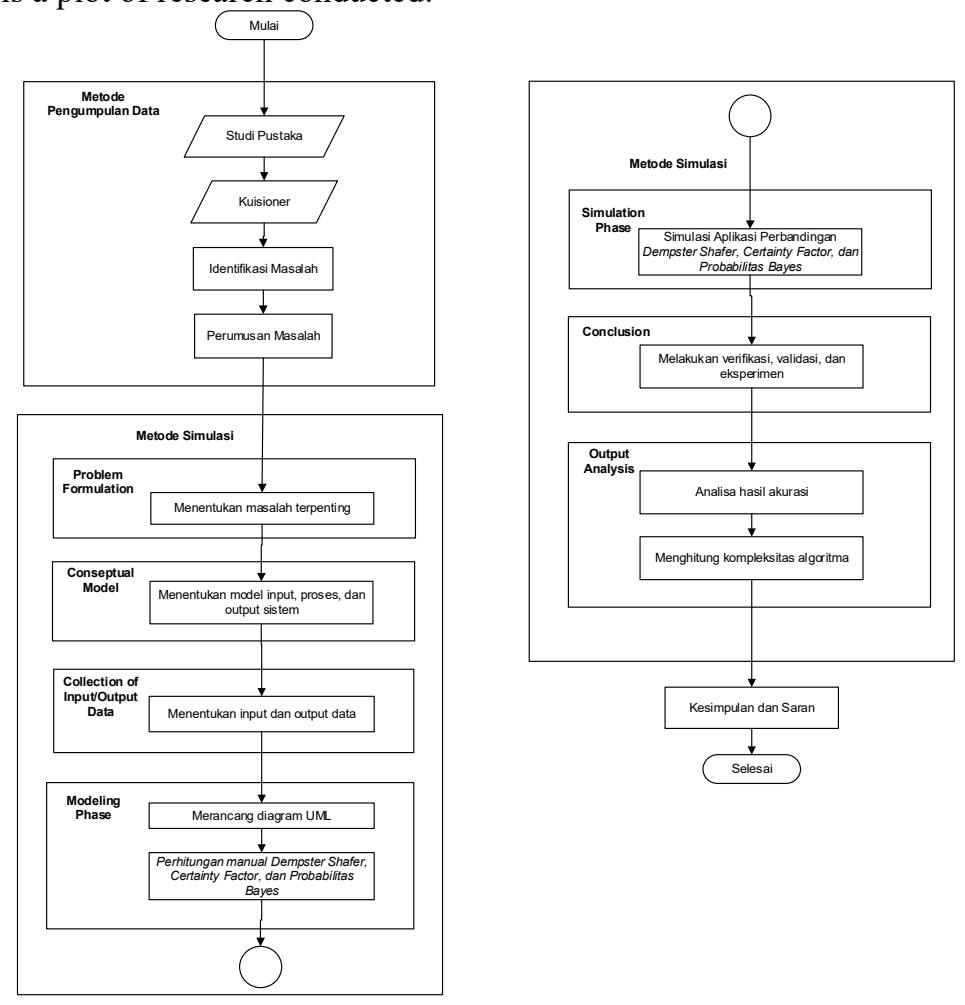

Fig 1. Flow Research

\section{Result and Discussion}

Subchapter This would explain the results of testing and comparison of the results of the method of Certainty Factor, Dempster Shafer, Bayesian probability on ticket reservation ships.

After testing 3 times the value of the parameter symptoms and damage that has been made based on the relationship between symptoms and damage, then the following is the result of the conclusion of the testing that has been done.

Here is the scenario:

- $\quad$ scenario 1

\begin{tabular}{|c|c|}
\hline Parameter & variable \\
\hline Damage & 1 Damage (Compass Error) \\
\hline symptom & 8 Symptoms \\
\hline Method & Certainty Factor, Dempster Shafer, Bayesian Probability \\
\hline
\end{tabular}


- $\quad$ scenario 2

\begin{tabular}{|c|c|}
\hline Parameter & variable \\
\hline Damage & 1 Damage (Battery Damaged) \\
\hline symptom & 6 Symptoms \\
\hline algorithm & Certainty Factor, Dempster Shafer, Bayesian Probability \\
\hline
\end{tabular}

- $\quad$ scenario 3

\begin{tabular}{|c|c|}
\hline Parameter & variable \\
\hline Damage & 1 Damage (Gimbal Motor Error) \\
\hline symptom & 6 Symptoms \\
\hline algorithm & Certainty Factor, Dempster Shafer, Bayesian Probability \\
\hline
\end{tabular}

Here is a relational table between symptoms, damage, and the weights:

Table 1. Table Relationships Symptoms, Damage, And Weight

\begin{tabular}{|c|c|c|c|c|c|c|}
\hline No. & $\begin{array}{l}\text { Diagnosis } \\
\text { Codes }\end{array}$ & $\begin{array}{l}\text { Damage } \\
\text { Diagnosis } \\
\text { Name } \\
\end{array}$ & Name Symptom (Symptom Code) & MB & MD & Weight \\
\hline \multirow{6}{*}{1} & \multirow{6}{*}{ P001 } & \multirow{6}{*}{$\begin{array}{l}\text { compass } \\
\text { Error }\end{array}$} & Unmeasured height position (G001) & 0.5 & $0: 33$ & $0: 17$ \\
\hline & & & $\begin{array}{c}\text { The position of the distance is not } \\
\text { measured (G002) }\end{array}$ & $0: 55$ & $0: 22$ & $0: 33$ \\
\hline & & & $\begin{array}{c}\text { Maps on the preview monitor is not } \\
\text { directed (G016) }\end{array}$ & 0.65 & $0: 15$ & $0: 50$ \\
\hline & & & $\begin{array}{l}\text { Fly system for the GPS mode does } \\
\text { not match the position (G018) }\end{array}$ & 0.8 & $0: 13$ & 0.67 \\
\hline & & & $\begin{array}{l}\text { Unable to determine the location of } \\
\text { the position of drones in real time } \\
\text { (G019) }\end{array}$ & 0.9 & 0:07 & 0.83 \\
\hline & & & $\begin{array}{l}\text { The position of the drone when the } \\
\text { fly is not stable at the maximum } \\
\text { height (G022) }\end{array}$ & 1 & 0:01 & 0.99 \\
\hline \multirow[t]{2}{*}{2} & \multirow[t]{2}{*}{ P002 } & \multirow[t]{2}{*}{ IMU Error } & $\begin{array}{c}\text { The layout position of the monitor } \\
\text { with a late drone drone actual } \\
\text { circumstances (G020) }\end{array}$ & 0.8 & 0.3 & 0.5 \\
\hline & & & $\begin{array}{c}\text { Position drone during unstable fly at } \\
\text { a height of at least (G023) }\end{array}$ & 1 & 0:01 & 0.99 \\
\hline \multirow{4}{*}{3} & \multirow{4}{*}{ P003 } & \multirow{4}{*}{$\begin{array}{l}\text { Gimbal } \\
\text { Motor Error }\end{array}$} & $\begin{array}{l}\text { Unable to stabilize the position of the } \\
\text { camera (G003) }\end{array}$ & 0.5 & $0: 25$ & $0: 25$ \\
\hline & & & $\begin{array}{l}\text { Gimbal movement undirected } \\
\text { (G004) }\end{array}$ & 0.65 & $0: 15$ & 0.5 \\
\hline & & & $\begin{array}{c}\text { The camera can not be used to record } \\
\text { images stably (G009) }\end{array}$ & 0.8 & 0:05 & 0.75 \\
\hline & & & $\begin{array}{l}\text { Unable to calibrate the camera } \\
\text { gimbal (G026) }\end{array}$ & 1 & 0:01 & 0.99 \\
\hline
\end{tabular}




\begin{tabular}{|c|c|c|c|c|c|c|}
\hline No. & $\begin{array}{l}\text { Diagnosis } \\
\text { Codes }\end{array}$ & $\begin{array}{l}\text { Damage } \\
\text { Diagnosis } \\
\text { Name } \\
\end{array}$ & Name Symptom (Symptom Code) & MB & MD & Weight \\
\hline \multirow[b]{2}{*}{4} & \multirow[b]{2}{*}{ P004 } & \multirow{2}{*}{$\begin{array}{c}\text { motherboard } \\
\text { Error }\end{array}$} & drone can not fly (G006) & 0.65 & $0: 15$ & 0.5 \\
\hline & & & $\begin{array}{l}\text { drone does not turn on but the } \\
\text { indicator lights on (G013) }\end{array}$ & 1 & 0:01 & 0.99 \\
\hline 5 & P005 & Broken Arm & $\begin{array}{l}\text { The position of the drone at the time } \\
\text { of initial unstable fly drones take off } \\
\text { and at any height (G024) }\end{array}$ & 1 & 0 & 1 \\
\hline \multirow{5}{*}{6} & \multirow{5}{*}{ P006 } & \multirow{5}{*}{$\begin{array}{l}\text { Damaged } \\
\text { batteries }\end{array}$} & Fast full at the time in charge (G012) & 0.5 & 3 & 0.2 \\
\hline & & & $\begin{array}{l}\text { drone does not turn on and the } \\
\text { indicator lights off ( } \mathrm{G} 014)\end{array}$ & 0.6 & 0.2 & 0.4 \\
\hline & & & There notif damage batteries (G015) & 0.7 & 0.1 & 0.6 \\
\hline & & & Batteries Capacity Weakens (G030) & 0.85 & 0:05 & 0.8 \\
\hline & & & Propeller Round weakened (G032) & 1 & 0:01 & 0.99 \\
\hline \multirow{4}{*}{7} & \multirow{4}{*}{ P007 } & \multirow{4}{*}{ Board Beeps } & $\begin{array}{l}\text { drone can not fly for a long time } \\
\text { (G007) }\end{array}$ & 0.5 & $0: 25$ & $0: 25$ \\
\hline & & & $\begin{array}{l}\text { Fly system for the GPS mode does } \\
\text { not match the position (G018) }\end{array}$ & 0.75 & 0.5 & $0: 50$ \\
\hline & & & Request firmware updated (G025) & 0.9 & $0: 15$ & 0.75 \\
\hline & & & Dreadlocks can not be used (G031) & 1 & 0:01 & 0.99 \\
\hline \multirow{3}{*}{8} & \multirow{3}{*}{ P008 } & \multirow{3}{*}{$\begin{array}{l}\text { Gimbal } \\
\text { Motor } \\
\text { Overload }\end{array}$} & $\begin{array}{l}\text { Unable to stabilize the position of the } \\
\text { camera (G003) }\end{array}$ & 0.5 & $0: 22$ & $0: 33$ \\
\hline & & & Gimbal movement fractures (G005) & 0.95 & $0: 29$ & 0.66 \\
\hline & & & $\begin{array}{l}\text { Can calibrate the camera gimbal but } \\
\text { not the center position (G027) }\end{array}$ & 1 & 0:01 & 0.99 \\
\hline \multirow{3}{*}{9} & \multirow{3}{*}{ P009 } & \multirow{3}{*}{$\begin{array}{l}\text { Ultrasonic } \\
\text { sensors }\end{array}$} & $\begin{array}{c}\text { Maps on the preview does not } \\
\text { display the position (G017) }\end{array}$ & 0.5 & $0: 22$ & $0: 33$ \\
\hline & & & $\begin{array}{l}\text { Location of drones frequently } \\
\text { changing positions and does not } \\
\text { correspond to the actual position of } \\
\text { the drone (G021) }\end{array}$ & 0.95 & $0: 29$ & 0.66 \\
\hline & & & $\begin{array}{l}\text { Unable to provide information } \\
\text { regarding the nearest object (G029) }\end{array}$ & 1 & 0:01 & 0.99 \\
\hline \multirow{3}{*}{10} & \multirow{3}{*}{ P010 } & \multirow{3}{*}{$\begin{array}{l}\text { Flexible } \\
\text { cables }\end{array}$} & $\begin{array}{l}\text { The camera can not be used for } \\
\text { recording at all }(\mathrm{G} 010)\end{array}$ & $0: 55$ & $0: 22$ & $0: 33$ \\
\hline & & & $\begin{array}{c}\text { No images on the preview monitor } \\
(\mathrm{G} 011)\end{array}$ & 0.95 & $0: 29$ & 0.66 \\
\hline & & & $\begin{array}{l}\text { There is an error message when want } \\
\text { to calibrate the camera (G028) }\end{array}$ & 1 & 0:01 & 0.99 \\
\hline \multirow[b]{2}{*}{11} & \multirow[b]{2}{*}{ P011 } & \multirow[b]{2}{*}{$\begin{array}{l}\text { Motor } \\
\text { Damage }\end{array}$} & $\begin{array}{c}\text { drone can not fly up to a maximum } \\
\text { height (G008) }\end{array}$ & 0.65 & $0: 15$ & 0.5 \\
\hline & & & $\begin{array}{l}\text { Propeller round does not correspond } \\
\text { to commands from the remote } \\
(\mathrm{G} 033)\end{array}$ & 1 & 0:01 & 0.99 \\
\hline
\end{tabular}


From the calculation of each scenario with all three methods: Dempster Shafer, Certainty Factor, and Probability Bayes in getting the average value Accuracy, Recall, precission and Error Rate of each of the following methods of calculation result table of each method:

Table 2 Results of the final output Dempster Shafer, Certaimty Factor, and Probability Bayes

\begin{tabular}{|c|c|c|c|}
\hline $\begin{array}{c}\text { Results Confusion } \\
\text { Matrix }\end{array}$ & $\begin{array}{c}\text { Dempster } \\
\text { Shafer }\end{array}$ & $\begin{array}{c}\text { certainty } \\
\text { Factor }\end{array}$ & $\begin{array}{c}\text { probability } \\
\text { Bayes }\end{array}$ \\
\hline Accuracy & $81.81 \%$ & $87.87 \%$ & $84.84 \%$ \\
\hline recall & $100 \%$ & $100 \%$ & $100 \%$ \\
\hline precission & $33.33 \%$ & $42.85 \%$ & $37.50 \%$ \\
\hline error Rate & $18.18 \%$ & $12.12 \%$ & $15.15 \%$ \\
\hline
\end{tabular}

at $81.81 \%$ Accuracy parameter, Recall $100 \%$, precission $33.33 \%$, and $18.18 \%$ Error Rate, for Certainty Factor method has a parameter value at $87.87 \%$ Accuracy, Recall $100 \%, 42.85 \%$ precission, and Error Rate of $12.12 \%$, while the method of Bayesian probability values for the parameters Accuracy $84.84 \%$, Recall $100 \%$, precission $37.50 \%$, and $15.15 \%$ Error Rate.

\section{Conclusions}

Based on the analysis of the stages which have been described previously, the researchers concluded as follows:

1. An expert system for web-based damage to the drone's been running with the maximum.

2. Web-based expert system for damage drone support with responsive display that allows users to access it.

3. The processing results of the three methods terhadapa scenarios then searched results for Accuracy, precission, Error Rate, and Recallthe results of the calculation process of the three methods with quantitative assessment experts confidence, using the theory of Confusion Matrix and refer to the table 5:14 point subchapter 5.6, the result is $81.81 \%$ the accuracy of the method Dempster Shafer, $87.87 \%$ the accuracy of the method of Certainty Factor, and $84.84 \%$ on the accuracy of Bayesian probability method.

It can be concluded that on its basis for these three methods have almost the same level of accuracy that only has a difference of $00.03 \%-00.06 \%$ to be used as a search decision in determining a damage to the drone.

Acknowledgements. This research supported by UIN Syarif Hidayatullah Conference Grant for ICONQUHAS 2019

\section{References}

[1] Amanda, 2016. Comparison of Certainty Factor and Dempster-Shafer to the calculation result of "Diagnosis of Diabetes Mellitus", 
[2] Bunafit Nugroho, 2014. Making Web Programming Academic Information Systems School in PHP-MySQL \& Dreamweaver, Yogyakarta,

[3] Mayang Sari Dewi, 2013. For Disease Diagnosis Expert System In Dragon Fruit Plant Method Using Dempster Shafer, Riau.

[4] Emanuel Riolan, 2014. Comparative Analysis of Dempster-Shafer method Certainty Factor Method In Children Disease Diagnosis, Bogor.

[5] Emirul Bahar, 2016. Definition And Types of Drone along with the history of its development

[6] Feby Trianisa, Ade Supriatna. Expert System to Detect Damage to iPhone Method Using Certainty Factor,

[7] Juewanto, Muhammad Sholeh, Erfanti Fatkhiyah. Expert System Detection Method Using DSLR Camera damage CF (Certainty Factor),

[8] Kendall, JE \& Kendall, KE 2012. Analysis and Design System. Jakarta.

[9] Kusrini, 2017. Expert Systems Applications Determining Factor Uncertainty Quantification Methods Users with questions. Yogyakarta.

[10] Marimin, 2017, decision support systems and expert systems. Bogor,

[11] Musawarman, 2012. Rapid Application Development with Sharia Compliance. Depok,

[12] Raco, JR 2012. Qualitative Research Methods Types, Characteristics and superiority. Jakarta. PT. Gramedia Widiasarana Indonesia.

[13] Raharjo Budi, Imam Heryanto, Enjang Rk. 2012. Module Web Programming HTML, PHP and MYSQL. Bandung: Modula

[14] Rita Hamdani, 2016. Application of Bayes Method Development In Diagnosing Disorders in Children.

[15] Rosa A. S and M. Saladin. 2014. Learning Module Software Engineering (Structured and Object Oriented). Bandung.

[16] Toto Haryanto, 2011. Methods of Certainty Factor (CF).

[17] Trianda Syahputra, 2017. Expert System for Diagnosing Anemia Disease Method Using Bayes Theorem

[18] Suryo Atmojo, Ruli Utami. Damage Expert System Web Pendiagnosa General Children and HMFD Using Certainty Factor 